\title{
Turizmde Robotlaşma: Yiyecek-İçecek Sektöründe Robot Şefler ve Robot Garsonlar
}

\author{
DOI: 10.26466/opus.899296 \\ * \\ Gizem Özgürel $^{*}$ - Songül Kılınç Şahin** \\ * Dr.Öğr.Üyesi, Balıkesir Üniversitesi, Balıkesir/ Türkiye \\ E-Posta: gizem.ozgurel@balikesir.edu.tr \\ ORCID: $0000-0002-1161-3721$ \\ ** Öğr. Gör., Muğla Sıtkı Koçman Üniversitesi, Muğla/ Türkiye \\ E-Posta: songulkilinc@mu.edu.tr \\ ORCID: 0000-0002-3510-9220
}

\section{Öz}

Son dönemlerde teknolojideki heyecan verici gelişmelerden biri de turizm sektöründeki robot kullanımının yaygınlaşmasıdır. Robotların sağlık, ilaç, kimya, gıda ve tarım endüstrilerinde bir işçi gibi çalıştırılmalarının yanı sıra turizm sektöründe de benzer şekilde çalıştırılmaya başlandığ görülmektedir. Günümüzde turizm işletmeleri iş süreçlerinde teknolojiyi kullanmadıkça başarılı olamazlar. Diğer sektörler gibi yiyecek-içecek sektörü de Covid-19 pandemisinden en çok etkilenen sektörler arasında yer almaktadır. Bu kriz, gıda sektöründeki tüm işletmeler için yeni bir çağın başlangıcı olmuştur. Covid-19, insanlar birbirleriyle temas ettiğinde yayılan, oldukça bulaşıcı etkiye sahip bir virüs türüdür. Bu nedenle, yiyecek-içecek işletmeleri için insan temasının en düşük seviyede tutulmasın sağlayan robot teknolojisinin etkin bir şekilde kullanımı daha da önemli hale gelecektir. Bu çalışmanın öncelikli amact, robot-insan etkileşimi, turizm sektöründe robotların kullanım alanı özellikle yiyecekiçecek sektöründe robot şeflerin ve robot garsonların mevcut durumu ve geleceğe yönelik eğilimlerine yer vermektir. Çalışma amacı doğrultusunda, konuyla ilgili turizm alan yazın incelenerek ikincil veri olan daha önceki araştırmalardan yararlanılarak derleme yoluyla gerçekleştirilmiştir. Anahtar kelimeler (turizmde robotlar, robotlaşma, robot-insan etkileşimi örnekleri vb.) ile google, google scholar ve science direct'te son yıllarda yapılan çalı̧̧malar taranmış, sektör uygulamaları derlenmiş̧ir. Araştırma sonuçları kapsamında, turizm sektöründe robotların kullanım alanlarının giderek artacağ görülmektedir. Yiyecek-içecek sektörü de turizm sektörünün bir alt kolu olarak gelişmelerden doğrudan etkilenmektedir. Bu nedenle, yakın gelecekte yiyecek-içecek sektöründe de robot garsonlar, robot şefler gibi çalışanları görme ihtimalimiz artmaktadır.

Anahtar Kelimeler: Robot-İnsan Etkileşimi, Robot Şefler-Garsonlar, Yiyecek-İ̧ecek Sektörü, Covid-19, Turizmde Robotlar 


\title{
Robotics in the Tourism: Robot Chefs and Robot Waiters in Food-Beverage Sector
}

\begin{abstract}
One of the most exciting technological developments within the tourism sector in recent years has been the increased prevalence of robots. Robots can be employed as an employee in the tourism sector along with health, medicine, chemistry, food and agriculture industries. Nowadays, unless tourism firms use to technology in their works process they cannot be succesful. Like other sectors (for example education, travel, entertainment etc.), the food and beverage sector is among the sectors most affected by the Covid19 pandemic. The Covid-19 pandemic crisis has started a new epoch in the food industry. Covid-19 is a type of virus with a highly contagious effect that spreads when people come into contact with each other. Therefore, the implication of the robot technologies which proves untouched by human hand, will become more significant for the food service industry. The primary aim of the present study is to discuss the human-robot interaction, the current situation of robot technology in tourism sector, especially the use of robot chef, and robot waiters in food and beverage businesses and future trends. For this study, the tourism literature on the subject was examined and a review was made using the secondary studies, which were secondary data. Reference search includes searching with keywords (robots in tourism, robotics, robot-human interaction eg.) from published journals, research reports and studies in google, google scholar and science direct recent years. Within the scope of the study results, the use of robots will increase in the tourism sector in future. The food and beverage sector, as a sub-branch of the tourism sector, is directly affected by the developments. For this reason, robots can be employed as a waiter robots or chef robots in food and beverage business in the near future.
\end{abstract}

Key Words: Human-Robot Interaction, Robot Chefs-Waiters, Food and Beverage Sector, Covid19, Robots in Tourism. 


\section{Giriş}

Robot teknolojilerinde yaşanan gelişmeler, geleneksel endüstriyel robotlarından, hizmet robotlarına kadar uzanmıştır. Hizmet robotlarının; müzeler, sergiler, alışveriş merkezleri, oteller ve restoranlar gibi kamusal ortamlardaki çoklu görevleri ve kullanımları robotik alanında araştırılmakta ve geliştirilmektedir. Özellikle yiyecek-içecek hizmetlerinde, hizmet robotlarının geliştirilmesi ile ilgili çalışmalar son yıllarda giderek artmıştır (Pieska, Luimula, Jauhiainen ve Spiz, 2013, s.192). Covid-19 pandemi sürecinde, yeni normalde, robotların gerek üretim gerekse hizmet sunumunda daha çok yer almaları düşüncesi, turizmde robotlaşma uygulamaları ile robot-insan ilişki ve etkileşimlerini incelemeyi araştırmacllarca daha önemli bir hale getirmiştir. Turizmde yeni teknolojilerin uygulanması, robotların turizm deneyim alanları içerisinde yer almasına yol açmıştır. Turist-yerel halk ve turist-turizm çalışanı ilişkilerinde, turistin memnuniyeti, destinasyona ve turizme yönelik olumlu tutumları aralarındaki insan-insan etkileşiminin olumlu olmasına bağlıdır. Yaşanan değişim ve dönüşüm ile robotların kişilerarası temasın yerini almaya başlamasının, şimdiye kadar turizm alan yazınında teorize edilenin ötesine geçeceği öngörülmektedir (Tussyadiah, 2020, s.2).

Turizm sektöründe; çalışma biçimlerinin şekillenmesinde, iş modellerinin oluşturulmasında, ilişki ve etkileşimler ile hizmet sunumlarında robot teknolojisi etkisini göstermeye başlamıştır. Turizm alan yazınında robotlar ile ilgili yapılmış akademik çalışmaların oldukça sınırlı olduğu belirtilmektedir (Ivanov ve Webster, 2017, s.1; Murphy, Hofacker ve Gretzel, 2017, s.105; Mil ve Dirican, 2018, s.2; Yalçın Kayıkçı ve Kutluk Bozkurt, 2018, s.60). Son birkaç yılda turizmde robotlaşma uygulamalarına olan ilgi daha da artmıştır. Bu durum alan yazında yapılan akademik çalışmalara da yansımıştır (İbiş, 2019; Yalçın Kayıkçı ve Kutluk Bozkurt, 2018; Yıldız, 2018, 2019; Doğan ve Vatan, 2019; Murphy, Gretzel ve Pesonen, 2019; Bozkurt Uzan ve Sevimli, 2020; Ivanov ve Webster, 2019a, 2019b, 2020; Fuentes-Moraleda, Díaz-Pérez, Orea-Giner, Muñoz- Mazón ve Villacé-Molinero, 2020; Kılıçhan ve Y1lmaz, 2020; Tussyadiah, 2020; Tussyadiah, Zach ve Wang, 2020; Lu, Zhang ve Zhang, 2021; Vatan ve Doğan, 2021). 
Yeni ve sürekli gelişen bir alan olan robot-insan ilişkilerinin turizmdeki güncel yansımasının görülmesi, çalışmanın yapıldığ 1 dönemdeki durumun ortaya çıkartılması ve geleceğe ilişkin bakış açısı kazandırması açısından önemini göstermektedir. Bu çalışma, ulusal ve uluslararası alan yazın incelemesi şeklinde gerçekleştirilmiş ve araştırmacılara yol göstermesi amaçlanmıştır. Yapılan çalışmanın -yaşanan hızlı teknolojik gelişmelere paralel olarak- güncel gelişmelerin ve alan yazındaki uygulamaların derlenmesi yoluyla sektör paydaşlarına ve araştırmacılara katkı sağlayacağı düşünülmüştür. Bu çalışma ile turizm sektöründe robotlaşma, robot-insan ilişkileri ve yarattığı etkiler, robot şefler ve garsonlar ile sektördeki uygulama örnekleri açıklanmaya çalışılmış, sonuç ve tartışma bölümü ile çalışma sonlandırılmıştır.

\section{Turizm Sektöründe Robotlaşma}

Turizm sektöründe yer alan işletmeler turistlerin ihtiyaç ve isteklerini karşılamak üzere konaklama, yiyecek-içecek, ulaştırma, seyahat, rekreasyona yönelik ürün ve hizmetleri sunmaktadırlar. Konaklama işletmeleri içerisinde yer alan oteller, oberj ve hosteller ile apart oteller vb. turistlerin sadece geceleme ihtiyaçlarının ötesinde yeme-içme, eğlenme ve diğer ihtiyaç ve isteklerine cevap verebilecek çeşitli hizmetler üretmektedirler. Yiyecek-içecek işletmeleri, turistlerin evden uzak kaldıkları seyahatlerinde yeme-içme, sosyalleşme ve diğer psikolojik ihtiyaç ve isteklerine yönelik hizmetler üreten, 1 . sinıf restoranlardan, kafeterya ve eğlence yerlerine farklı servis biçimleri ve menüleri ile çeşitlilik arz eden işletmelerdir. Hava, kara, deniz ve demiryolu işletmeleri, turistin coğrafi hareketliliğini sağlayarak, güvenli, konforlu bir biçimde destinasyona ve çekiciliklere ulaşabilmesini sağlamaktadır. Turistlerin turistik ürünlere ulaşmasında dağıtım görevini üstlenen, üretici-toptancı olarak paket turlar hazırlayan tur operatörleri ve bu paket turların satışı, turiste bilgi verme, araç kiralama vb. hizmetleri sunan, perakendecilik işlevini yerine getiren seyahat acentalarıdır. Temalı parklar ve kış sporları merkezleri, boş zaman değerlendirmeye yönelik turistik hizmet üreten işletmelerdir. Söz konusu işletmeler açık veya kapalı mekânlarda turistlerin eğlenmesi, hoşça vakit geçirmesi veya kış sporlarına yönelik aktivitelere katılımlarını desteklemek 
için çeşitli ortamlar yaratmaktadırlar. Yüzer tesisler ve karayolu üzerindeki mola yerleri de diğer turizm işletmeleri grubunda yer almakta ve turistlerin yeme-içme, dinlenme vb. istek ve beklentilerine cevap vermeye çalışmaktadırlar.

Turizm işletmeleri tarafından yaratılan mekânlar, robot teknolojisinin deneyimlenebilmesi için uygun ortamlar sunmaktadır. Turizm işletmelerinde robot uygulamalarına geçmeden önce robot kavramını açıklamak yerinde olacaktır. Robot kavramı sözlüklerde, "Belirli bir işi yerine getirmek için manyetizma ile kendisine çeşitli işler yaptırılabilen otomatik araç." (Türk Dil Kurumu, 2021) veya "işleri otomatik olarak gerçekleştirmek için kullanılan bir bilgisayar tarafindan kontrol edilen bir makine."(Cambridge Dictionary, 2021) olarak tanımlanmaktadır. Lin, Abney ve Bekey (2011, s.943) robotlarl; "algılayan, düşünen ve hareket etmek üzere tasarlanmış makineler" olarak tanımlamışlar ve insanların yerini alacak şeyler olarak görülebileceklerini belirtmişlerdir. Bu bağlamda robotları, örgütlerin veya insanların ihtiyaç ve isteklerine cevap vermek üzere tasarlanan, karmaşık görevleri komut verildiğinde yerine getirebilen makineler veya yapay zekâ destekli akıllı aracılar olarak tanımlamak mümkündür.

Uluslararası Robotik Federasyonu robotları (International Federation of Robotics, 2020); endüstriyel robotlar ve hizmet robotları olarak sinıflandırmaktadır. Uluslararası Standardizasyon Örgütü'ne (International Organization for Standardization, 2012) göre endüstriyel robot, "otomatik olarak kontrol edilen, yeniden programlanabilen, çok amaçl robotik kollara sahip olabilen robot"; hizmet robotu ise "endüstriyel otomasyon uygulamaları dışında insanlar veya ekipman için yararl görevler gerçekleştiren robottur".

Turizm ve misafirperverlik bağlamında hizmet robotlarını; turizm işletmelerinin misafirleri ile çok dilli iletişim kurabilen, etkileşen, yeni teknolojik çalışanlar olarak tanımlamak mümkündür. Van Doorn ve diğerleri (2017, s.44) turizm sektöründe robotları; "hizmet deneyimlerinde rol alan sosyal aracılar" olarak tanımlamışlardır. Hizmet robotları, bir turizm işletmesinin müşterilerine hizmet sunan, onlarla iletişim kuran, etkileşim içerisine girebilen, sistem tabanlı özerk, uyarlanabilir ara yüzler olarak da tanımlanabilmektedir (Wirtz vd., 2018, s.909).

Günümüzde insanlığın hizmetine sunulmuş bulunan ve geliştirilen robotlar çeşitli roller üstlenmektedir. Bu roller Lin vd. (2011, s.944-945) tarafından şu şekilde açıklanmıştır: 
- İşçilik ve hizmetler: Süpürme, biçme, yıkama, ütüleme, nesneleri odadan odaya taşıma, imalat ve üretim süreçlerinde yer alma.

- Askeri ve güvenlik: Casusluk, gözetleme, yaralılara yardım, bombaları etkisiz hale getirme, ülke sınırlarını, binalarını ve hatta evleri koruma.

- Araştırma ve eğitim: Okyanus tabanından veya Marstan bilgi toplama, sınıflarda öğrencilere ders verme, öğretme, etkileşim içerisine girme ve katılımı kontrol etme.

- Eğlence: Eğitici eğlence [edutainment] veya eğitim-eğlence odaklı görevleri yerine getirme, çocuklar için robotik oyuncaklar vasıtasiyla sosyalleşme ve ahlaki gelişimine katkı sağlama.

- Tip ve sağlık hizmetleri: Terapötik amaçlar için hazırlanmış Paro gibi robotlar; stres azaltma, bilişsel aktiviteyi teşvik etme ve sosyalleşmeyi geliştirme. Tip uygulamalarında zor görevlerin başarılmasında Ares gibi yutulabilir tıbbi robotların kolaylaştırma işlevleri.

- Kişisel bakım ve refakatçiler: Ri-Man ve Papero gibi robotların çocuk ve yaşlı bakımında üstlendikleri işler.

- Çevre: Çöp toplama, toksinleri koklama, kirli alanları tespit etme, küresel isınma verilerini toplama ve benzeri görevleri yerine getirme yer almaktadir.

Turizm sektöründeki başarının her şeyden önce rekabet gücüne ve kalite faktörü olarak insan kaynağına bağlı olduğu genel olarak kabul edilmektedir. Söz konusu kabule karşın, hizmet üretiminde robotik uygulamalar, robotlara en basit görevlerin verilmesiyle başlamıştır (Brotons Martínez, 2012 akt., Fondevila Gascón vd., 2019, s.54). Bilim ve teknoloji alanında yaşanan gelişmeler, turizmde robotlaşma uygulamalarının; rehberlikten, danışmanlığa, oda servisinden robot şeflere ve garsonlara uzanan özellikli rolleri ile sektördeki varlığını her geçen gün daha çok hissettirmektedir.

Otellerde, Hilton Worlwide'da Softbank'ın 'NAO" robotları, InterContinental Grup bünyesinde "Dash", Clarion Hotel Amarantende "Amazon Echo", Starwood grubunda "Botlr"; oda servisi, taksi çağırma, çevrimiçi bilgi paylaşımı, sohbet veya konsiyerj (concierge) hizmetlerinden bir ya da bir kaçını yerini getirmektedir (Crook, 2014; Hamacher, 2015; Trejos, 
2016; Murphy vd., 2017, s.108; Prentice, Lopes ve Wang, 2020, s.741). Hizmet robotlarının ilk defa otel işletmelerinde kullanımı 2015 yılında Nagazaki Japonya'da açlan Henn na Hotel tarafından gerçekleştirilmiştir (Reis, Melao, Salvadorinho, Soares ve Rosete; 2020, s.2). Henn na Hotel; 3 farklı dili çok iyi derecede konuşan, misafirleri karşılayan, ön büroda giriş-çıkış işlemlerini yapabilen, istekleri ve şikâyetleri kayıt altına alabilen 186 robot çalışanı ile Guinness Dünya Rekorları kitabına giren ilk oteldir (Jarvis, 2016; Papathanassis, 2017, s.211). Hilton McLean Tysons Corner, Aloft Hotel Cupertino gibi diğer otel işletmelerinde de robot çalışanları görmek mümkündür (Trejos, 2016). 2018 yılı sonunda ise Alibaba Grup'a ait geleceğin ilk insansız oteli "Flyzoo Hotel" faaliyete geçmiştir (Hertzfeld, 2018). "Care-o-bot", "Rhino", "Relay", "Hermes", "Minerva", "Pepper ve Nao", "Sage ve Chips", "Urbano", "Cicerobot", "Robovie", "Toyota" ve "Tinny" isimli robotlar Avrupa'dan Amerika'ya, uzak doğudan Asya'ya müzelerde rehberlik hizmeti sunmaktadırlar. Havacılık alanında; Amsterdam Schiphol Havalimanı'nda "Spencer", İstanbul Havalimanı'nda robot "Mini $A D A$ ", Royal Dutch Airlines'ta "Care-E" yolculara rehberlik, bagaj taşıma, sesli yol tarifi, uçuş bilgisi sorgulamasına sesli yanıt gibi hizmetler sunmaktadirlar (Tussyadiah, 2020, s.1; www.akinsoft.com.tr, 2019).

Turizm sektöründe robotlaşma; yürütülen operasyon süreçlerini iyileştirme, işletme performansını arttırma, hizmet kalitesini yükseltme, kişiselleştirilmiş ürünleri geliştirme açısından birçok fırsat sunmaktadır. Turizm işletmelerinin teknolojik uygulamalarıyla, yenilikçi ve yaratıcı hamleleriyle, rekabet üstünlüğü elde etmede robotları daha çok tercih edeceği düşünülmektedir (Ivkov, Bleši'c, Dudi'c, Pajtinková Bartáková ve Dudi'c, 2020, s. 1). Robotların sektörde kullanımı ile birlikte bazı iş türlerinin önemli oranda azalabileceği ya da tamamen ortadan kalkabileceği, bazı iş türlerinin ise yapılış yöntemlerinin yeniden şekillenebileceği öngörülmektedir (Ivanov, 2020, s.210-211).

Hizmet robotlarının turizm sektöründe kullanımının yeni olması nedeniyle alan yazında bu konu ile ilgili yapılan çalışmalar çok sınırlıdır. Ivanov, Webster ve Berezina (2017) robotların turizm işletmelerine uyumu, Tung ve Law (2017) ise turizm sektöründe insan-robot etkileşiminde yaşanan deneyim konuları ile alandaki ilk araştırmaları yapmışlardir. 
Yildız (2018) çalışmasında; "profesyonel turist rehberlerinin (PTR) teknolojik rehberlere (TR) ilişkin algılarını" keşfetmeye odaklı 16 katılımcının dahil olduğu nitel bir araştırma yapmıştır. Araştırmasında; TR'in PTR'ne olan ihtiyacı azaltacağ 1 (9 katılımc1), robotların insana benzer düşünme ve hissetme niteliklerine sahip olsalar bile TR'lerin bir insan turist rehberi gibi rehberlik hizmeti veremeyeceği (11 katılımc1), PTR'lerden (10 kattlımcı) çoğunluğunun TR'i kendi mesleki durumları ile ilgili bir tehdit olarak algılamadıkları, TR'lerin varlığının işe yönelik tutumlarında (6 katılımcı) ve iş performanslarında ( $11 \mathrm{katılımcı)} \mathrm{bir} \mathrm{etki} \mathrm{yaratmadı̆̆ı/yarata-}$ mayacağı, robot teknolojik rehberlerin gelecekte açık alan rehberliği yapmalarına ilişkin ihtimal vermedikleri (10 katılımc1), katılımcıların tamamının TR'lerin rehberlik hizmeti performanslarını oldukça yetersiz bulduklarını tespit etmiştir.

Fuentes-Moraleda ve diğerleri (2020) çalışmalarında, otellerdeki hizmet robotları ile etkileşime giren turistleri, insan-robot etkileşimi ekseninde araştırmışlardır. 74 otelin 7994 Tripadvisor çevrimiçi yorumunu, Hizmet Robotu Kabul Modeli'ne göre işlevsel, sosyal-duygusal ve ilişkisel boyutları ile duygu analizi de yaparak incelemişlerdir. Araştırmacılar; modelin insan-robot etkileşiminde yer alan temel boyutları, değişkenleri ve farklı turist türlerinde ilham verdiği duyguları açıladığı sonucuna ulaşmışlardır. Ayrıca araştırmacılar, çoğunlukla işlevsel boyut hakkında yorum yapıldığını, robotların işlevlerinin deneyimi belirlediği ve robotlar ile otel konukları arasındaki etkileşimi etkilediğini tespit etmişlerdir.

Tussyadiah ve diğerleri (2020), akıllı otonom teknolojilerine olan güveni ölçmek için otonom transfer ve robot barmenleri içeren iki araştırmayı kapsayan bir çalışma yapmışlardır. Araştırmacılar, akıllı robotlara güven inancının öncüllerini ve sonuçlarını araştırdıkları çalışmalarında, akıllı makinelere duyulan güvenin, teknolojiye karşı olumsuz tutumdan ve teknolojiye güvenme eğiliminden etkilendiği, -şaşırtıc bir biçimde- robotların fiziksel formunun güveni etkilemediği sonuçlarına ulaşmışlardır. Çalışmada ayrıca yapılan her iki araştırma sonucuna göre güvenin benimseme niyetine yol açtığını tespit etmişlerdir.

\section{Turizm Sektöründe Robot-İnsan İlişkilerinin Etkileri}


Hizmet üretim ve tüketiminin, turist-ev sahibi/turizm çalışanı (insan-insan) etkileşimi ile gerçekleştiği turizm sektöründe, turist memnuniyeti ve turizm destinasyonlarına yönelik olumlu tutumlar, insan temasları ile şekillenmektedir. Turizm sektöründe robotlaşma, turizm deneyimlerinde insanların etkilerinin ve etkileşimlerinin potansiyel kaybı, robot-insan etkileri ve etkileşimleri içinse önemli bir potansiyel barındırmaktadır (Ivanov ve Webster, 2019a, s.247; 2019b, s.259). Robotik ilişkiler aynı zamanda turizm sektöründeki geleneksel misafirperverlik anlayışına -bir bakıma psikolojik ve duygusal olarak- meydan okumayı temsil etmektedir ( $\mathrm{Lu}$, Cai ve Gursoy, 2019, s.37). Murphy ve diğerleri (2017) robot-insan ilişkilerinin sosyal ortamını süregelen bir muamma olarak görmektedirler.

Akıllı hizmet robotları, bir diğer ifadeyle yapay zekâ ile geliştirilmiş etkileşimli robotlar; kendilerine yöneltilen sorulara uygun cevaplar verme, ziyarete değecek cazibe merkezlerini önerme ve daha iyi performans için kendi kendine öğrenebilecekleri biçimde tasarlanmışlardır (Tussyadiah, 2020, s.5). Ancak robotların duygu ve kişisel dokunuş yoksunlukları (Yalçın Kayıkçı ve Kutluk Bozkurt, 2018, s.59), ilişki ve etkileşim durumlarında bir eksiklik olarak kendini göstermektedir. Her ne kadar günümüzde turizm sektöründeki genel eğilim, robotların sık tekrar gerektiren ve oldukça düşük düzeyde yaratıcılık barındıran görevlerine odaklanmış olsa da uzun vadede robotların daha karmaşık görevler üstleneceği yönünde beklentiler bulunmaktadır. İdeal bir robottan beklenen davranışları şu şekilde sıralamak mümkündür: Hızlı ve hassas bir makine gibi davranması, sosyal normlara bağlı kalması, empati yapabilmesi, ruh hali değişimi, hata ve önyargılardan uzak olmasıdır (Barnett vd., 2015, s.1134).

Fondevila Gascón ve diğerlerine (2019, s.59) göre gelecekte; robot-insan etki ve etkileşimlerinin insan-insan etkileşimine yakın ya da benzer hale getirilmesi olası görülmektedir. İnsan duygularının robotlarca anlaşılmasının sağlanması, özellikle turistler, işletmeler ve çalışanlar açısından herhangi bir risk taşımayan, tehlike yaratmayan, her açıdan güven veren, beden dili ile olumlu mesajlar gönderen robotların turizm sektörüne özel olarak yaratılması beklenmektedir. Belanche, Casaló ve Flavián (2020, s.3) hizmet robotlarının insana benzer tasarlanmasının, misafirlerin robot ile yakınlık algılarını (bir tür aşinalık ve daha yakın bağlantı olarak) 
artırmak için araçsal bir değişken olarak görülmesi gerektiğini belirtmektedirler. Turizm deneyimlerinde, turistin merakını artıran ve ilgisini çeken geleceğin robotları, geliştirilmiş iletişim becerileri ile olumlu ilişki ve etkileşimler yaratarak, turist istek ve beklentilerini analiz ederek, hem turizm işletmelerinin hem de turistlerin beklentilerini karşılayabilir hale gelecektir. Ancak insan-robot etkileşiminde en yüksek yeteneğe sahip olan hizmet robotlarının insanlar tarafından kabulüne ilişkin Flandorfer $(2012$, s.1) tarafından yapılan araştırmada; yaş, cinsiyet ve eğitim düzeyi gibi sosyoekonomik değişkenlere göre hizmet robotlarının farklı düzeylerde kabulü, sosyal ilişkiler için durumun karışık ve muğlak olduğunu göstermiştir.

Turizm sektöründe işletmeler-çalışanlar ve turistler ile robotların ilişkilerinin yaratacağı etkiler; olumlu ve olumsuz etkiler olmak üzere iki başlık altında incelenebilir (Ivanov ve Webster, 2017, s.2-3).

- Olumlu Etkiler: Robotik teknoloji genel olarak verimlilik, veri saklama ve hafıza ile ilgilidir (Fondevila Gascón vd., 2019, s.54). Ekonomik açıdan; insan kaynağına emeği karşılığı ödenen ücret, prim, maaş zammı ödemeleri ile personel eğitimi, iş kazaları, tazminat vb. diğer ödeme kalemlerinde robot kullanımının sağlayacağ önemsenecek düzeydedir. Ayrıca robot kullanımı, hizmet kusurlarının azaltılması yoluyla turistik deneyime değer katarak, turistin memnuniyet düzeyini artırmaktadır. Emek yoğun bir sektör olan turizmde, mevsimsellik etkisinden uzak işletmelerde, hizmeti üreten insan kaynağı yılın 365 günü, günün 24 saati çalışmakta ve vardiya sistemi uygulanmaktadır. Hem 12 ay boyunca açık, hem de sezonluk çalışan turizm işletmelerinde robotların 7/24 kullanılması ile daha az insan kaynağına gereksinim duyulması, daha fazla hizmet üretimi, iş güvenliği ve meslek hastalığı problemleri gibi durumlarla karşılaşılmaması, zamansal ve parasal açıdan tasarruf sağlanmasına ve işletmenin operasyonel süreçlerde verimliliğine etki etmektedir (Belanche vd., 2020, s.1). Robotların misafirleri karşılamaları, isimlerini hatırlamaları, misafir memnuniyetini artırarak tekrar ziyaret niyetleri üzerinde ve devamlı, sadık misafirler yaratarak işletme gelirlerinin artmasında etki yaratabilecek potansiyel barındırmaktadır.

Robot-insan ilişkileri, hem dışa dönük hem de içe dönük misafirler açısından sosyo-psikolojik açıdan da olumlu etkiler yaratabilmektedir. Ro- 
botlar misafirlerin anadilinde iletişim kurabilmekte -çok dilli programlanabilme özellikleriyle- dil bir engel, önemli bir sorun olmaktan çıkmaktadır. Misafirlerin istek ve beklentilerinin karşılanması, gereksinim duydukları birçok bilgiye robotlar aracılığıyla kolayca ve hatta eğlenerek ulaşabilmeleri, algıladıkları hizmet kalitesi düzeyini artırmaktadır. Turizm işletmelerinde robotların varlığı, yenilikçi turizm işletmesi imajının yaratılmasinda (Kuo, Chen ve Tseng, 2017, s.2-12) önemli bir misyon üstlenmektedir.

Olumsuz Etkiler: Robotların; turizm işletmelerine olumlu etkileri yanında maliyet kalemleri ve mevcut düzenlenmelerdeki karmaşıklıklar gibi bazı sorunlar yaratması da söz konusu olabilmektedir. Robotların turizm işletmelerinde yaratabileceği olumsuz etkiler şunlardır (Ivanov ve Webster, 2017, s.3-4):

- Robotların edinilmesine bağlı ortaya çıkan ekonomik maliyetler (robot ücreti),

- Bakım masrafları,

- İşletmeye kurulumları ve adapte edilmeleri ile ilgili masraflar,

- Robot yazılımların güncellenme maliyetleri,

- Tesis düzenleme maliyetleri,

- Bakım-onarım için ek personel istihdamı,

- Dış kaynak kullanımına bağlı yazılımcı işletmeye ödenecek ücretler,

- Personel-robot-iş uyumunun sağlanması için insan kaynağına verilecek eğitimlerin maliyetleri,

- Robotun/robotların muhasebe sistemine nasıl kaydedileceği, bakım masrafları ve vergilendirme açısından nasıl bir yol izleneceğine ilişkin yasal düzenlemelerin bulunmaması, ortaya çıkacak karmaşa ve benzerleri sayılabilir (Mil ve Dirican, 2018, s.7).

Lin ve diğerleri (2011) robotik uygulamalardan kaynaklanan olumsuz etkiler yaratabilecek, 3 etik sorun alanına işaret etmişlerdir. Söz konusu etik sorun alanları; güvenlik zafiyeti ve teknik hatalar, yasal sorumlulukların belirsizliği ve olumsuz sosyal etkilerdir. Güvenlik zafiyeti ve teknik hatalar arasında; kodlama yanlışlıkları, siber güvenlik boşlukları, misafir mahremiyet ihlalinin yaratabileceği olumsuz etkiler sayılabilir. Yasal so- 
rumluluk belirsizliği; robotik hatalardan kaynaklanan zararlarda sorumluluğun kime ait olacağına ilişkin yasal düzenlemelerin yetersiz veya hiç yapılmamış olmasından kaynaklanan olumsuzluklardır. Ayrıca misafirlerin mahremiyetini tehdit edebilecek; dijital kameraların, dinleme-kayıt cihazlarının kötü amaçlı kullanımına ilişkin ortaya çıkabilecek olumsuz etkilere karşı misafir haklarını koruyan ek düzenlemeler ile sorumluların kimler/hangi işletmeler olacağının belirlenmesi gerekmektedir.

Uygulamada robotlarla ilgili karşılaşılan olumsuzlukların ilk örneklerinden biri Henn na Hotel'de yaşanmıştır. Otel yönetimi çalışanların iş yükünü ve maliyetleri düşürmedeki başarısızlığı nedeniyle, robot sayısının yarıdan fazlasını azaltma yoluna gitmiştir. Robotların sık sık bozularak misafirleri kızdırması, uzmanların tamir için çok zaman harcaması, misafir ve çalışanlardan çok sık şikâyet gelmesi nedeniyle çözüm olarak otelde robot sayısı azaltılmış, insan kaynağı tarafından üretilecek hizmetlere odaklanılarak insan kaynağı sayısı arttırılmıştır (Hertzfeld, 2019).

Robotik uygulamaların artarak devam etmesi, insanların sosyal ilişkilerini olumsuz etkileyebilecek bir gücü elinde bulundurmaktadır. Ancak robotların sosyal etkilerine ve yarattıkları sonuçlara ilişkin çalışmaların eksikliği göz önüne alındığında, insan ilişkilerinin robotik ilişkilerle değiştirilmesinin psikolojik zararlar ortaya çıkartıp çıartmayacağı belirsiz bir durumdur. Robotların, turizm sektöründe yaygın kullanımı, istihdam sorunlarına yol açabileceği gibi teknolojiye olan bağımlılığın artmasına ve insan yeteneklerinin zaman içerisinde kaybolmasına yol açabilecek potansiyel barındırmaktadır. Ayrıca doğrudan insana yönelik bir zarar vermese de dolaylı olarak elektronik atıkların (e-waste) çevreye vereceği zarar, tüm insanlığ bir diğer önemli olumsuz etkidir.

Küresel bir medya ticaret şirketi olan Travelzoo (2016), seyahat ve turizm sektöründe robotların, turistler tarafından kabul edilip edilmediğini araştırmıştır. Asya, Avrupa ve Amerika'dan 6.000'den fazla turistin katıldığı araştırmada katılımcıların;

- \%80'inin 2020'de robotların (aktif anlamda) hayatlarında önemli olmasın bekledikleri,

- \%75'inin robotlar ile hayatlarının daha iyi olacağına inandıkları, 
- Yaklaşık üçte ikisinin, seyahat endüstrisinde kullanılan robotlardan memnun oldukları,

- Tatil ve seyahatleri iyileştirmede robotları en az benimseyen milletlerin Almanlar ve Fransızlar, en çok benimseyenlerin ise Çinliler ve Brezilyalılardan oluştuğu,

- Katılımciların \%81'inin veri yönetimi ve \%79'unun konuşma dillerinde, robotların insanlardan daha iyi olacağını öngördükleri,

- \%76'sının ise robotların daha iyi bir hafızaya sahip olduğunu düşündükleri sonuçlarına ulaşılmıştır. Ayrıca Chan ve Tung (2019) robotik hizmetlerin, insan çalışanlardan daha yüksek düzeyde duyusal ve entelektüel deneyimler ile daha düşük düzeyde duygusal deneyimler sağlandığını belirtmektedirler.

İnsan-robot etkileşiminde güven ve güvenlik en önemli iki ana faktör olarak görülmektedir. Robotların kusurlu performans sergilemeleri güveni zedelemekte, hayal kırıklıkları ve öfke yaratmakta, kontrole yönelik güvenlikle ilgili uygulamalar misafirleri huzursuz edebilmektedir. Bu nedenlerden dolayı, etkin sosyal ilişkiler ve etkileşim için robotların yüz ifadelerini, davranış kalıplarını ve insan hareketlerini analiz edebilme yönlerinin geliştirilmesi gerekmektedir (Fuentes-Moraleda vd., 2020, s.9).

\section{Yiyecek-İçecek İşletmelerinde Robot Şefler ve Garsonlar}

Turizm sektöründe robot kullanımının artmasına paralel bir şekilde yiyecek-içecek işletmelerinde de robotların kullanımı yaygınlaşmaya başlamıştır. Yiyecek-içecek hizmeti veren işletmelerde insan şeflerin yerine ikame edilebilecek robot şefler yeni bir gerçeklik olarak görülmektedir (Berezina, Ciftci ve Cobanoglu, 2019 akt., Zhu ve Chang, 2020, s.1367). Robot şefler yemeği hazırlama, pişirme, servise sunma gibi görevleri üstlenen hizmet robotlarıdır. Operasyonel süreçlerine ve müşteri deneyimlerine robotik uygulamaları dâhil eden işletmeler, yemeği pişiren robot şeflerin yanı sıra misafirleri karşılayan, siparişleri alan ve hatta tüm servis sürecini yürütebilen robot garsonları da bünyelerine katmışlardır. Sektörde robotların kullanımı üretim ve servis süreçlerinin daha akılcı ve arzu edilir biçimde şekillenmesine yardımcı olmaktadır. Robotlar süt ürünleri, unlu mamuller, şekerlemeler, dondurulmuş gıdalar ve içecekler 
gibi farklı gıda üretim alanlarında; gıdaların taşınması, paketlenmesi, etiketlenmesi, paletlenmesi ve servis edilmesi noktalarında başarılı bir şekilde değerlendirilmektedir (Khan, Khalid ve Iqbal, 2018, s.13).

Gıda üretim alanında robotların direkt olarak gıda ile temas edecek şekilde çalıştırılması son dönemlerde artış göstermiştir. Gıda alanında çalışan robotların hijyen gerekliliklerini ve dezenfeksiyon prosedürlerini eksiksiz yerine getirecek şekilde tasarlanması önemlidir. Bunun için robotların hijyen kurallarına dikkat ederek bakımını yapabilecek şekilde tasarlanması için birçok çözüm uygulanmaktadır (Trienekens ve Zuurbier, 2008, s.108). Örneğin, robotların tüm dış parçaları denetlemeye ve elle y1kamaya uygun olacak şekilde ve erişilebilir durumda olmaları sağlanmaktadır. Robot şefler, temizlik prosedürlerini yerine getirecek şekilde endüstriyel deterjanlara ve tazyikli sıcak suya dayanıklı olacak şekilde tasarlanmaktadır (Holmes, 2014). Bu bağlamda, şu anda içinde bulunduğumuz pandemi döneminde tüm dünya ülkelerinde Covid-19 hastalığının kontrolü için alınan önlemlerde mesafe-el/yüzey hijyen kuralları temel alınmaktadır. Yiyecek-içecek işletmelerinde robot şeflerin ve garsonların kullanımı gerek insanların birbirleri ile olan temasının azaltılmasında, gerekse gıda alanlarındaki hijyen kurallarının eksiksiz yerine getirilmesi noktasında büyük avantajlar sağlayacaktır.

Gıda hijyeni, ürünlerin sağlıklı bir şekilde üretilebilmesi için çok önemlidir. Yapılan araştırmalarda, yiyecek ve içeceklerin üretimi sırasinda insan elinin temas etmediği ürünlerde bakteri ve virüslere rastlanılmamıştır (Gunasekaran, 1996, s.247). Bunun yanı sıra, robot şefler ağır ve zorlu çevre koşullarında çalışmaya uygun şekilde tasarlanmaktadır. Örneğin; Pizza fırınının önünde $800^{\circ} \mathrm{C}$ sıcaklı̆̆a kadar dayanabilecek özellikte olabilmektedirler (Foto 1a). Bir diğer taraftan misafirlerin önünde ekmekleri fırınlayan robot şefler, dikkatleri üzerlerine çekerek hayranlik yaratabilmektedirler (Foto $1 b$ ). 


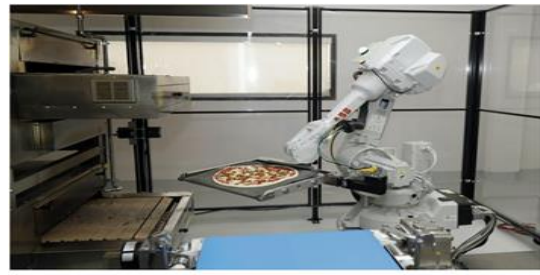

(a)

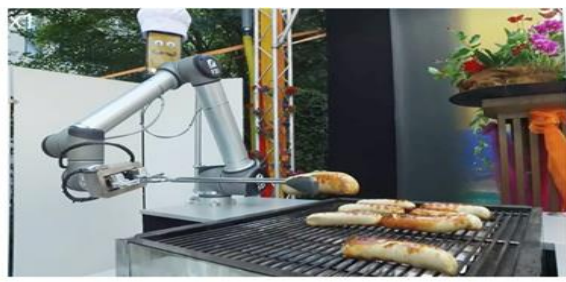

(b)

Foto 1a; 1b: Robot Şefler

(Kaynak:(1a) CBS News, 2016; (1b) Altish, 2016)

Gıda üretimi sırasında, robot şeflerin gerek gıda güvenliği açısından, gerekse performans açısından sağlamış olduğu avantajlardan dolayı Pizza Hut ve McDonald's gibi birçok fast food zinciri, gida üretiminde tamamen robot şeflerin kullanımı ile ilgili planlama yapmaktadır (Sedacca, 2016).

Dünyanın ilk örnek robot şefi AUSCA Kasım 2017 tarihinde M Social Singapur Oteli'nde misafirlere kahvaltıda yaklaşık 2 dakika 30 saniyede yumurta (sahanda yumurta ve omlet tarzında) hazırlatılarak tanıtılmıştır. 2018 y1lı sonunda ise Orchard Hotel Singapore, Grand Copthorne Waterfront Hotel Singapore, M Hotel Singapore, Studio M Hotel Singapore ve Copthorne King's Hotel Singapore olmak üzere Singapur'daki diğer 5 otel işletmesi de robot şefi mutfaklarında kullanmaya başlamışlar$\operatorname{dir}(\underline{w w w} \cdot$ hospitalitynet.org,2018).
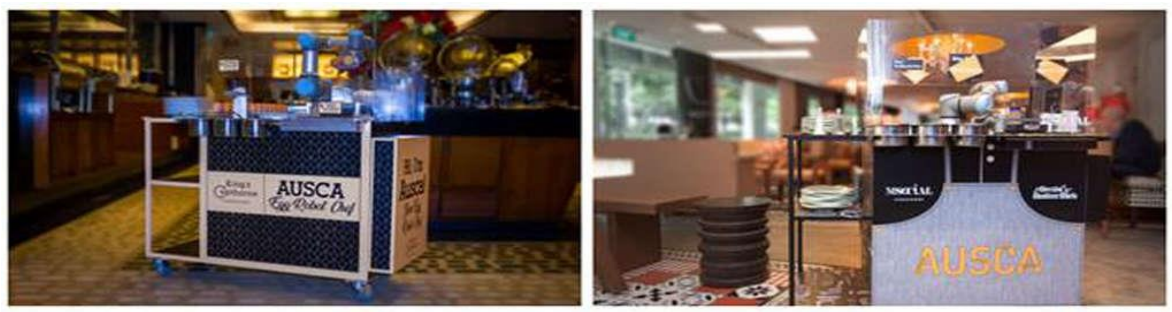

Foto 2. Ilk Örnek Robot Şef AUSCA

Kaynak: www.hospitalitynet.org, 2018.

Yüksek teknoloji ile dizayn edilen ve Çin'de üretilen, AIKE olarak adlandırılan diğer bir robot şef 751 farklı yemek reçetesini hafızasında depolayıp 3 dakika içerisinde 24 farklı geleneksel Çin yemeğini otantik tadı ile hazırlayabilmektedir (Mathath ve Fernando, 2017, s.293). 
Boston Danışmanlık Grubu'nun 2015 yılında yapmış olduğu çalışmaya göre, gelecek 10 yıl ve devamında robotların performans artışı ve maliyet düşürmesi gibi artı değerlerinden dolayı hizmet sektöründe kullanımının kayda değer şekilde artacağı öngörülmektedir (www.bcg.com, 2015). Asya'daki hizmet sektörü, robotların bu avantajlarından hali hazırda faydalanmaktadır. Binlerce noodle yapan şef robotlar, Çin'deki restoranlar tarafından satın alınmaktadır. Singapur'daki birçok restoran mutfaktan servis alanına yiyecekleri taşıyacak garson robotları kullanmaktadır. Robot garsonların maliyeti 10 bin doların altındadır. Günde yaklaşık 8 saat çalışmakta ve yaşam süreleri yaklaşık 5 yıl olarak tahmin edilmektedir. Çin'in Ninbo şehrindeki bir restoranda 2 robot garson misafirlerden siparişi aldıktan sonra, yemeklerini servis etmekte ve misafirlerle kendi dillerinde 40 farklı cümle (afiyet olsun, lütfen bana yol verebilir misin?, teşekkürler vb.) kurabilme yetenekleri ile iletişim içerisine girmektedirler (Collins, 2015, s.23).

Lu ve diğerleri (2021) çalışmalarında; restoranlardaki hizmet robotlarının farklı seviyelerdeki insana benzer özelliklerinin (örneğin görsel, sesli ve sözlü) tüketim sonuçlarını (örneğin hizmet karşılaşma değerlemesi, tekrar ziyaret nedenleri ve olumlu ağızdan ağıza iletişim niyetleri) ve altında yatan mekanizmaları biliş yoluyla nasıl etkilediğini araştırmışlardır. Çalışmalarında; insan benzeri sesin her 3 tüketim sonucunu da etkileyen baskın bir özellik olarak ortaya çıtığı, insani dil stilinin tüketim üzerindeki etkisinin yalnızca olumlu duygularla açıklandığı ve hizmet karşılaşması değerlendirmesinin hem biliş (yani algılanan güvenilirlik) hem de duygu ile açıklandığı sonuçlarına ulaşmışlardır.

Seyitoğlu ve Ivanov (2020) dünyanın robotik restoran deneyimini araştıran ilk çalışmalardan birisini yapmışlardır. Çalışmalarında, gezginlerin robotik restoran deneyimlerini (7 ayrı ülkeden, 582 katılımcının, 13 farklı robotik restorandaki deneyimlerine yönelik yorumları) incelemişler ve deneyim bileşenlerinin bir modelini sunmuşlardır. Araştırmacıların ortaya çıkardıkları robotik restoran deneyim modeli 6 ana temel temayı içermektedir. Bunlar: Çocuklar için cazibe, robotik sistem, unutulmaz deneyim, ambiyans ile ilgili özellikler, yemek ile ilgili özellikler (ekonomik değer ve gastronomik yönler) ve fark edilen eksikliklerdir (robotik sistemde ambiyans ve gida ile ilgili eksiklikler). 


\section{Robot Şef ve Garsonlara İlişkin Sektördeki Uygulama Örnekleri}

Robotlar son dönemlerde, turizm sektöründe konaklama işletmelerinin yiyecek-içecek departmanlarında, lokantalarda, fast food işletmelerinde, yiyecek-içecek servisinde bulunan çeşitli işletmelerde; servis personeli, barmen-barmaid, asistan şef, şef gibi görevleri üstlenmektedirler (Ivanov ve Webster, 2020, s.1067; Fust'e-Forn'e, 2021, s.1).

Caliburger fast food işletmesi Amerika Birleşik Devletleri'nin California eyaletinde Flippy adını verdiği robot şefin hazırladığı hamburgerleri servis etmektedir. İlk otonom robotik mutfak asistanı Flippy, 1zgara başında köfteleri istenilen kıvamda pişirmenin yanı sıra fritöz başında yiyecekleri kızartabilme becerilerine sahiptir. Flippy'nin giriş seviyesi fiyatı 60.000 \$'dır ve ortalama bir hamburger şefine bir yılda yapılan ödemeden oldukça yüksektir. Ayrıca robotun bakımı için yıllık \% 20 oranında yinelenen bir masrafı bulunmaktadır. Ancak Caliburger, azaltılmış bekleme süreleri, tutarlılık ve azalan yiyecek israfı sayesinde yatırımın geri dönüşünden emin olduğunu belirtmektedir (CaliBurger, 2016; Heater, 2018).

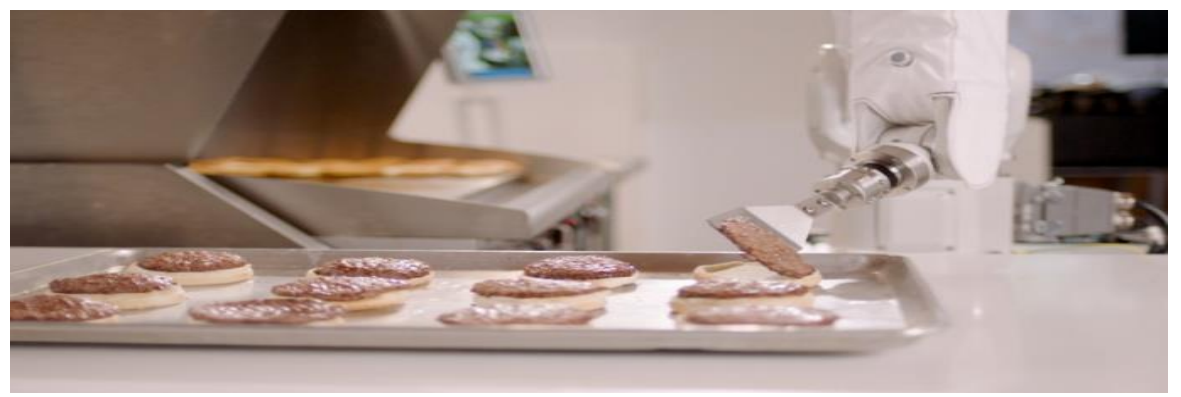

Kaynak: Heater, 2018.

Foto 3. Flippy

Massachusetts Teknoloji Enstitüsü'ndeki bir grup öğrenci ile ünlü şeflerden Daniel Boulud'un birlikte yarattıkları Boston'daki Spyce adlı restoranın mutfağı, tam otomatik olarak tasarlanmış olup robot şefler görev yapmaktadır (Doyle, 2018). Ayrıca Spyce çok aşamalı, karmaşık yemeklerin dahi hazırlanabildiği dünyanın ilk robotik mutfağına sahiptir (Holley, 2018). Robot teknolojinden yararlanan restoranlar arasında ayrıca; Bankok'taki Hajime Robot Restaurant (The Smart Local Tailand, 
2020); Çin'in Jiyan eyaletindeki Dalu Robot Restaurant (www.designboom.com, 2010) ve robotik barmenleri ile öne çıkan Royal Caribbean bulunmaktadır (Royal Caribbean International, 2021).

Dünyada 400'den fazla mağazası bulunan zincir suşi restoranlardan biri olan Japon Kura Sushi firması, suşilerin hazırlanmasında, robot şeflerden faydalanmaktadır. Dokunmatik ekrandan siparişini veren misafirlere, ürünleri hazırlandıktan sonra taşıyıcı konveyörler aracılığı ile siparişleri teslim edilmektedir (Restaurant Technology News, 2019).

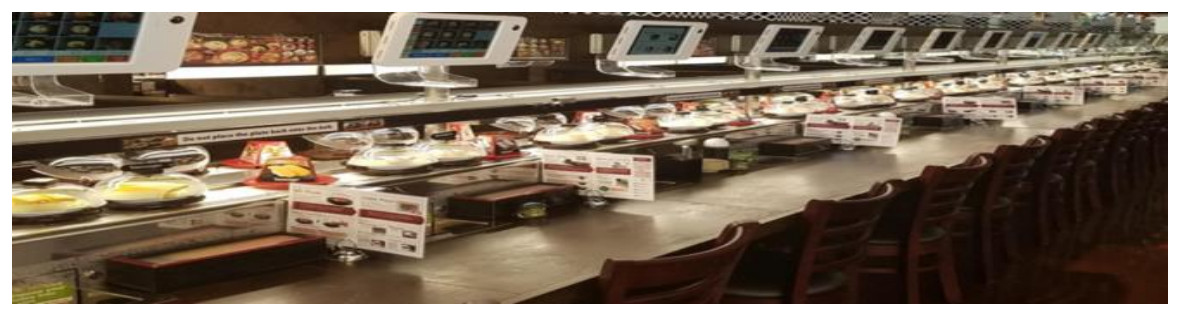

Foto 4. Kura Sushi

Kaynak: Restaurant Technology News, 2019.

Amerika Birleşik Devletleri'nin Kaliforniya Eyaleti'nde bulunan Zume Pizza işletmesi de mutfağında pizzaların yapımında robot şeflerden faydalanmaktadır (Khan vd., 2018, s.19). Zume Pizza'da robotlar ekip çalışması sayesinde pizzaları istenilen lezzette misafirlere sunmaktadır. Pepe ve Giorgio adlı robotlar pizza hamuruna domates sosların dökerken, Marta robot hamurdaki sosu yayma işini üstlenmektedir. Bruno adlı robot pizzayı fırına yerleştirme görevini yaparken, Vincenzo robot ise fırından pizzayı çıarma işini yapmaktadır (Robinson, 2018).

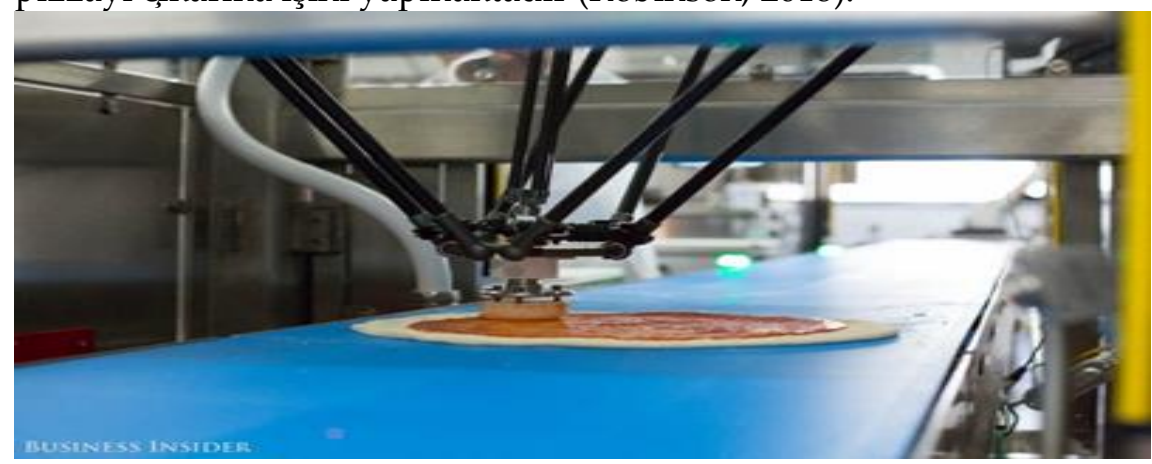

Foto 5. Zume Pizza 
Kaynak: Robinson, 2018.

Bangkok'ta bulunan Hajime Robot Restaurant, Japon yemeklerinin servis edildiği, robot garson ve şeflerin görev aldığı diğer bir yiyecek-içecek işletmesidir (Kinder Travel Guide, 2021).

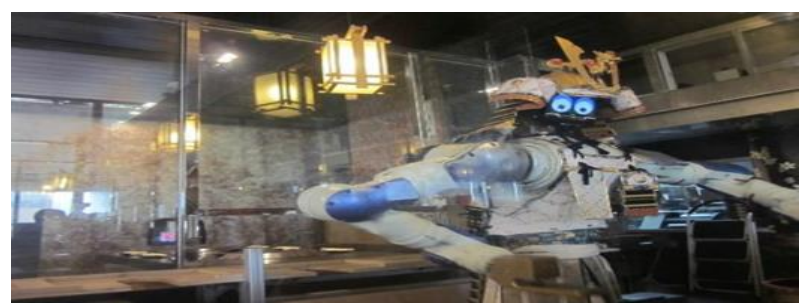

Foto 6. Hajime Robot Restaurant

Kaynak: Kinder Travel Guide, 2021.

Boston'da robotik mutfağa sahip olan Spyce Restaurant'ta misafirler, dijital menüden istedikleri malzemelerden oluşan yemekleri sipariş etmekte; alınan siparişler, robot şefler tarafından pişirilmekte ve servis edilmektedir. Son dokunuşların yapılabilmesi ve garnitürlerin tabağa ilave edilmesi için 2 personel yeterli olmaktadır. Restoranın direktörü Michelin yıldızlı şef Daniel Boulud'tur (Moon, 2018).

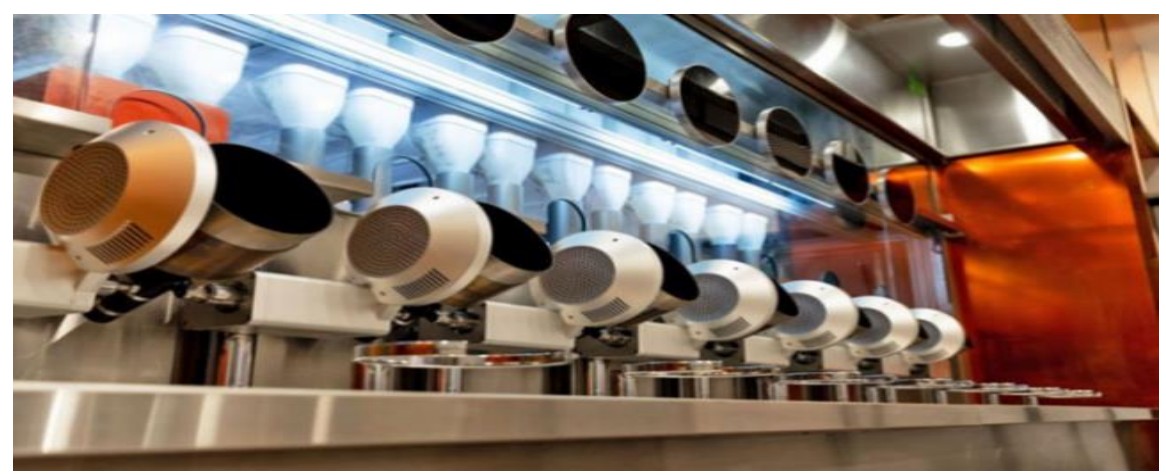

Foto 7. Spyce Restaurant

Kaynak: Moon, 2018.

Taze meyve sebzelerle salata yapan robot Chowbotics, Kaliforniya bölgesinde bulunan Redwood City'de yer almaktadır. İnsanların daha 
sağlıklı beslenmelerine destek olmak amaciyla Chowbotic robotlar taze malzemelerle (biber, domates ve peynir gibi 22 farklı malzeme) çeşitli salata seçeneklerini hazırlayıp sunabilmektedir (Kopp, 2019).

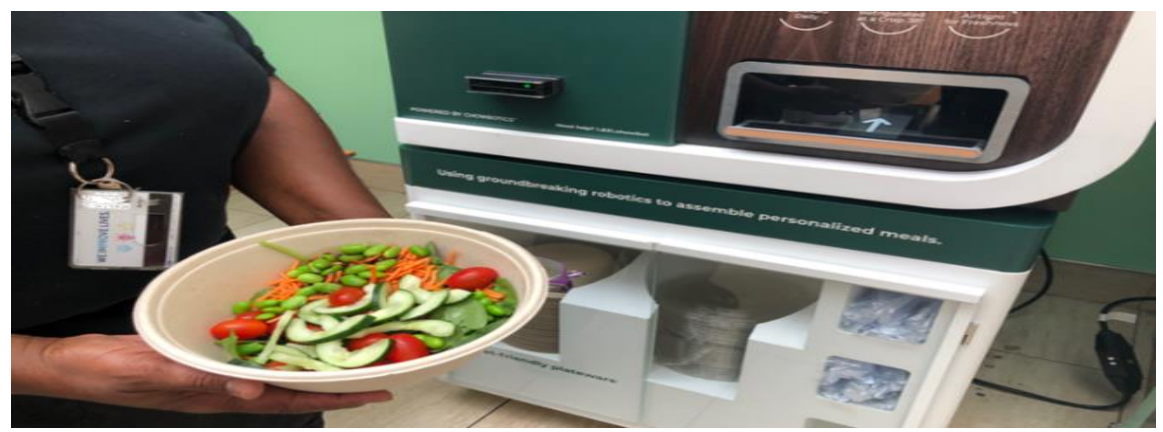

Foto 8: Chowbotic Robot

Kaynak: Kopp, 2019

Pizza Hut işletmesinin Asya'daki mağazalarında kullandığı Pepper robot işletmeye gelen misafirlere, yemek seçenekleri konusunda öneriler sunacak şekilde dizayn edilmiştir. Benzer şekilde, Çin'deki bir başka restoran ise maliyeti düşürmek amacıyla çalışan insan garsonların yerine robot garsonlar alarak hizmet vermeyi tercih etmiştir. Çin'deki yiyecek-içecek işletmelerinde robotların kullanımı her geçen gün artış göstermektedir (Khan vd., 2018, s.19).

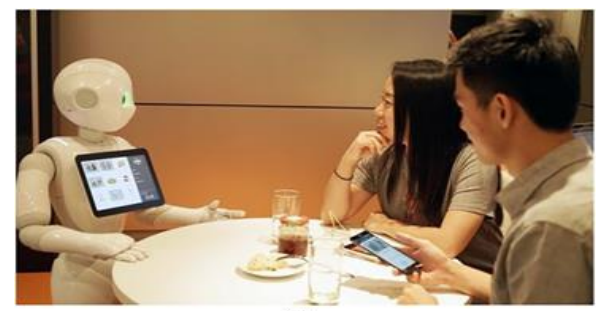

(a)

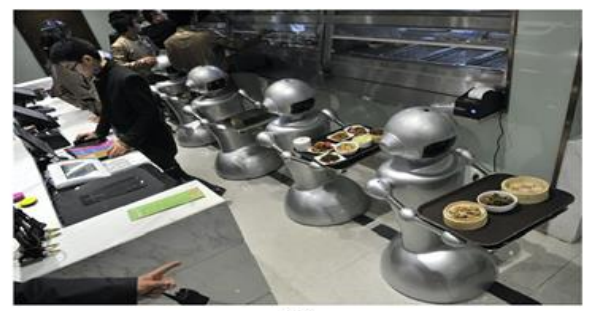

(b)

Foto 9. Robot Garsonlar

Kaynak: (13a) Pizza Hut Pepper Robot (Reisinger, 2016);(13b) Restaurant Robots in China (Nguyen, 2016).

Çin'in Jinan şehrinde faaliyet gösteren Dalu Robot Restaurant'ta 6 robot garson ve misafirleri karşılayan 2 hizmet robotu görev yapmaktadır. 
Restoranda hizmet robotları, yiyecek-içecek servislerini daire biçiminde tasarlanmış hatta bisikletle getirmektedir. Restorandaki garson robotlar, aynı anda 100 müşteriye hizmet sunabilmektedir (www.turkiyeturizm.com, 2010). Çin'de bulunan diğer bir robot restoran ise "I Robot"tur. Restoranda 2 robot şef, 3 dakika içerisinde, yaklaşık 100 çeşit Çin yemeğini hazırlayabilme yeteneğine sahiptir. Robot şeflerin en önemli ayrıcalıkları; etkin operasyonları ve hijyenik olmalarıdır (Mathath ve Fernando, 2017, s.291).

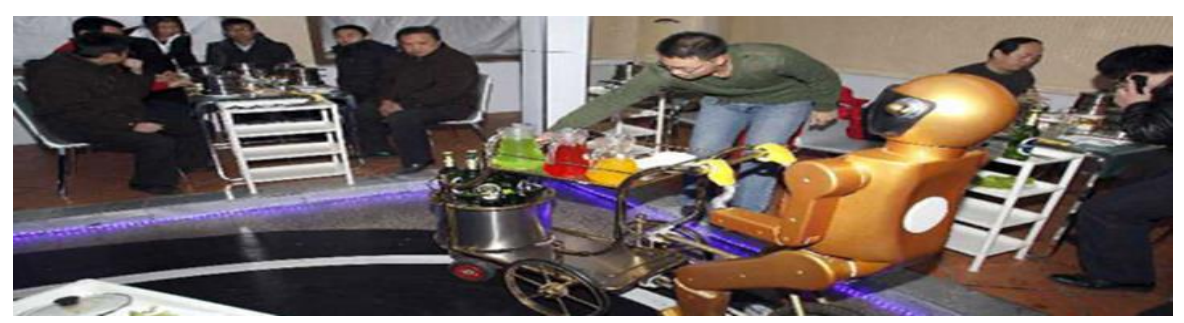

Foto 10. Dalu Robot Restaurant

Kaynak: www.turkiyeturizmcom, 2010.

Misafirlerine teknolojisinin avantajını kullanarak farklı bir deneyim yaşatmak isteyen Royal Caribbean Cruise firması (Symphony of the Seas, Ovation of the Seas, Harmony of the Seas, Quantum of the Seas ve Anthem of the Seas) gemilerinde yer alan Biyonik barlarında robot barmenlerin hazırladıkları kokteylleri ile dikkat çekmektedir (Silverstein, 2020).

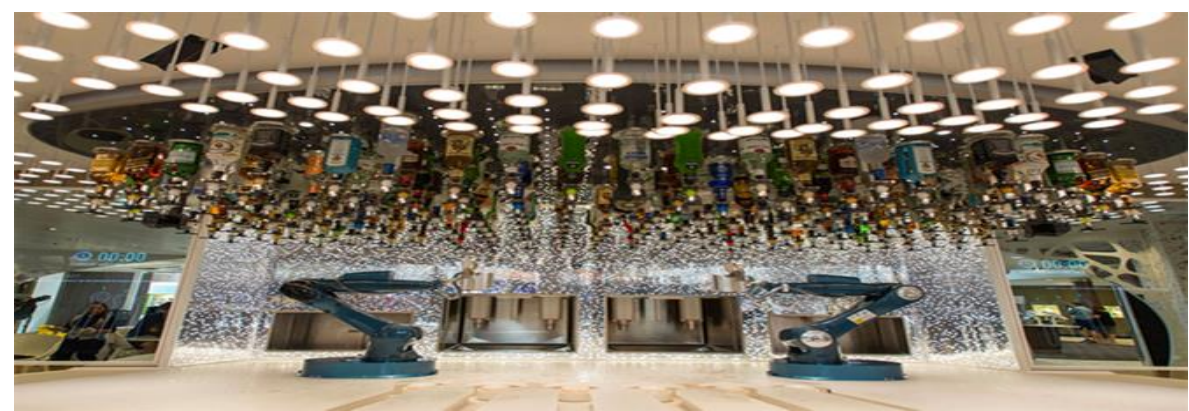

Foto 11. Robot Barmenler

Kaynak: Silverstein, 2020. 
Türkiye'de ise Konya ilinde bulunan bazı yiyecek-içecek işletmelerinde Akın robotik işletmesi tarafından üretilen hizmet robotları servis hizmetlerini yerine getirmektedir (Yülek, 2018).

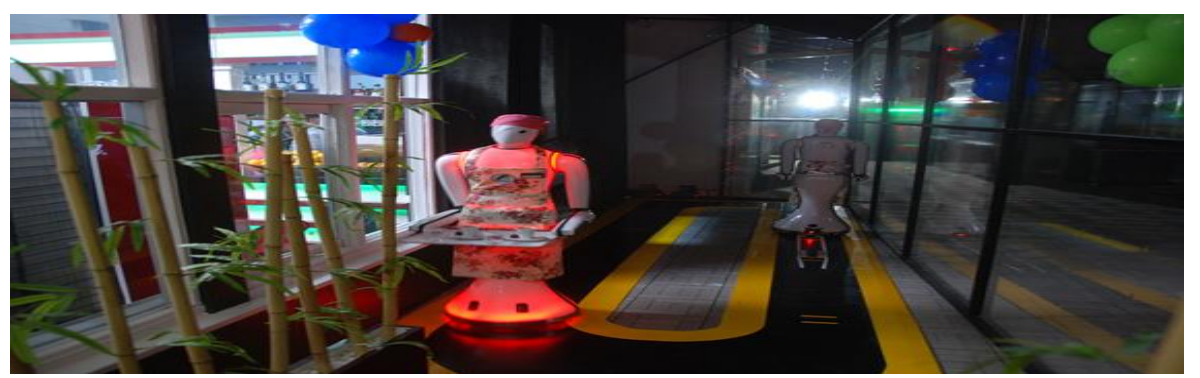

Foto 12.150 m Boyunda, 30 kg A ̆̆ırlı̆̆ında Yapay Zekâya Sahip AKINSOFT Tarafından Tasarlanan Garson

Kaynak: www.akinsoft.com.tr, 2015.

\section{Sonuç ve Tartışma}

Turizm sektöründe robotların varlığı her geçen gün giderek artmaktadır. Turizm destinasyonlarında halka açık alanlarda, konaklama işletmelerinde, kruvaziyer gemilerde, seyahat acentalarında, havalimanlarında, müzelerde, temalı parklarda, kongre ve fuar organizasyonlarında, restoranlarda servis ve mutfakta robot çalışanlar, hizmet sürecine her geçen gün artan sayıda dâhil olmaktadırlar.

Sektörde yeni bir eğilim olan robot kullanımı, hizmet sunum süreçleri üzerinde etki yaratmakta ve misafirlerin ihtiyaç ile isteklerini yeni bir forma sokmakta, turistik deneyimleri ise yepyeni bir düzeye taşımaktadır (Ivkov vd., 2020, s.1). Covid-19 pandemisi ve benzeri hastalıklarla ilgili krizlerde, enfekte veya karantina altındaki misafirlere, mikrobiyal virüslerden etkilenmeyen robotlar etkin ve verimli bir biçimde hizmet verebilme potansiyeline sahiptirler (Seyitoğlu ve Ivanov, 2020, s.2).

$\mathrm{Bu}$ çalışmada; turizm sektöründe robotların kullanımı, özellikle robot şeflere ve garsonlara ilişkin yapılmış çalışmalara ve sektördeki uygulama örneklerine yer verilmiştir. Robot şefler; mutfakta gıdaların ön hazırlığını yapma (kesme, doğrama vb.), pişirme ve hatta sunum sürecine dâhil olma gibi birçok işlevi ve sorumluluğu yerine getirebilmektedir. Robot şeflerin 
özellikle hazır yemek (fast food) sektöründeki işletmelerde daha fazla tercih edildiği görülmektedir. Robot şeflerin zincir hazır yemek restoranlardaki kullanımının artmasına bağlı olarak, Türkiye'deki restoranlarda da robot şeflerin kullanılmaya başlanacağı öngörülmektedir.

Bucak ve Yiğit'in (2020) çalışmalarında, Covid-19 pandemi sonrasında yiyecek-içecek sektörü ve aşçılık mesleğinin geleceği ile ilgili Türk Şeflerinin Düşüncelerini araştırmışlardır. Araştırmacılar çalışmalarında, menü planlamasında yöresel ve sağlıklı ürünlere yönelik talebin artmasına bağlı olarak bazı değişikliklerin olabileceğini, gıda hijyeni ve güvenliği konusunun öneminin tekrar gündeme geleceğini vurgulamışlardır. Bu bağlamda robot şeflerin, gıda güvenliği konusunda işletmelere ve misafirlerine güven verebileceği ve robot şeflerin gelecek dönemlerde yiyecek- içecek sektöründe kullanımının artacağı söylenebilir.

Vatan ve Doğan'ın (2021), "otel çalı̧̧anlarımın robot garsonlar hakkındaki düşünceleri" üzerine yapmış oldukları çalışmada, robot garsonların operasyonel ve sistemsel olarak başarısızlığa yol açabileceğini ve teknik maliyeti arttırabileceğini belirtmişlerdir. Aynı çalışmada katılımcıların, robot garsonların sektörde işsizliğin artmasına neden olacağına ilişkin görüşleri vurgulanmıştır. Ayrıca, yapılan araştırma sonucunda, otel çalışanlarının robotlara komut verme noktasında olumlu düşünceler beslerken, robotlardan komut alma noktasında negatif düşünceye sahip oldukları tespit edilmiştir.

Robotların turizm sektöründe kullanımının giderek arttığı görülmektedir. $\mathrm{Bu}$ bağlamda, robotların turizm işletmelerindeki varlıklarının önemi ve faydaları ile ilgili verilecek olan eğitimler aracılığıyla çalışanların ön yargıları ortadan kaldırılabilir. Yine benzer eğitimler, turizm fakültelerinde de verilerek geleceğin turizm sektör çalışanlarının dünyadaki gelişmeleri daha rahat takip edebilmeleri ve uygulayabilmelerine katk1 sağlanacaktır.

Turizm sektöründe robot kullanımının yaygınlaşması öngörüsünden hareket ederek, robotlar ve turizm çalışanları, robotlar ve misafirler, robotlar ve diğer turizm paydaşları (tedarikçiler, aracılar vb.) ile ilişkiler ve yarattığı etkiler üzerine alandaki boşluğu doldurmak adına yapılması gereken birçok çalışma olduğunu belirtmek gerekmektedir. 


\title{
EXTENDED ABSTRACT
}

\section{Robotics in the Tourism: Robot Chefs and Robot Waiters in Food-Beverage Sector}

\author{
Gizem Özgürel - Songül Kılınç Şahin \\ Balıkesir University-Muğla Sıtkı Koçman University
}

Recent developments in information and computer technologies like artificial intelligence, nanotechnology, new generation wireless technology and robots bring about the occurrence of novel approaches and modern practices in tourism sector. Human relations plays very crucial role in tourism sector. Food and beverage industry is one of the tourism sector is also affected from the innovative technological developments. In the modern business rivalries the importance of robots is becoming pivotal for industrial applications. When computers were discovered to use for the business long time ago, they have been modified for the best suit for the different requirements. The end of the 2030, it has been predicted that robots will have being used the all industries regardless of the sector as computers are today (Mathath and Fernando, 2017, pp. 288).

While increasing the application of robots in food service industry, it can be categorized under culinary operation and front personnel operation. This innovative application bring about the emergence of the concepts such as robot waiter and robot chef especially in the food service sector. Also, robotic technologies engender to the rise in the competitiveness and marketing of the goods by providing quick service to customers (Mathath and Fernando, 2017, pp. 288). Nowadays the popular trends in food service sector like catering, food production firms, fast-food restaurant has revealed the robotic applications including robot waiter and robot chef in many countries around the world. The robot transformation in food industry has increased business productivity, reduced cost and enhanced customer experiences. Despite the wide use of robots in manufacturing and service sectors, the utilization in food service industry is a novel application. Currently, some food service firms throughout the world incorporated the use of robot waiter and robot chef for preparing, cooking and serving dishes. 
The COVID-19 pandemi crisis has began a novel era in the food sector. Like other industries, the food and beverage industry has been affected dramatically by impacts from the COVID-19 pandemic, which has induced gigantic losses in many sectors of the global economy. COVID-19 is highly contagious as it is transmitted by human-to-human contact. Therefore, evaluating the potential impact of the virus on food safety is an extremely important issue for governments, the food industry and consumers worldwide (Han et al., 2021, pp. 25). During the post- COVID-19 era, the food industry and food supply will increasingly depend on the development of resilient food systems which is including good hygiene practices, cleaning, sanitation, and maintaining social distance among workers in the food industry (Han et al., 2021, pp. 32). Effective food control systems are essential for protecting consumer health and safety. According to Mahalik and Nambiar (2009, pp. 590), food industry includes food production, food processing and food service; all of them incorporate robotic operations for different purposes (Erzincanlı and Sharp, 1997, pp. 195). Remarkable changes have been taken place in food industry globally. Stringent work conditions, extreme temperature, speedy process to produce low cost goods were the main requisites for the industry (Mahalik and Nambiar, 2009, pp. 591). According to Wilson (2010, pp. 499), the real business growth of the food industry lies at the implication of the concept"untouched by human hand "will become the significant marketing differentiator for the food products in the future. Low cost maintenance with high productivity in the food industry is considered as the prime advantage for the robots. Also, infection of food can be sifted and be ensured food safety by the usage of robots in food service sector. The success of the food industry is always dependent on product quality, consistency and high return on investment, and robots are meant to achieve all these necessities. Therefore, robots have a rising demands for the food and beverages industry especially post Covid 19. At the same time, robot waiters and robot chefs may lead to a soared unemployment rate in the future and communicational problems with customers.

The basic goal of this paper is to discuss the human-robot interaction, the present circumstance of robot technology in tourism industry, especially the use of robot waiter and robot chef in food and beverage businesses and the tendencies towards future are determined. For this study, 
a comprehensive literature on the subject was investigated and a review was made using the secondary studies which were secondary data through online search. The results of this study showed that in general, the use of robots will increase in the tourism industry in future. The food and beverage sector has a direct association with the tourism industry. The results of this study showed that there are so many examples of robot technology in the tourism industry and food service sector. The significant findings from the present study indicate that the use of robot waiter and robot chef in the food service sector will ascend in near future.

\section{Kaynakça/ References}

Altish (2016, Haziran 25). Restaurant robots: Service jobs are history. 5 Mart 2021 tarihinde https://altish3.rssing.com/chan-71370889/article2.html adresinden erişildi.

Barnett, W., Foos, A., Gruber, T., Keeling, D., Keeling, K. and Nasr, L. (2014). Consumer perceptions of interactive service robots: a value-dominant logic perspective. The 23rd IEEE international symposium on robot and human interactive communication, Edinburgh, UK, s. 1134-1139. doi: https://doi.org/10.1109/ROMAN.2014.6926404.

Belanche,D., Casaló, L., V. and Flavián, C. (2020). Frontline robots in tourism and hospitality: Service enhancement or cost reduction?. Electronic Markets, 1-16. doi:https://doi.org/10.1007/s12525-020-00432-5.

Bozkurt Uzan, Ş. ve Sevimli, Y. (2020). Gastronomideki robotik uygulamalar ve yapay zekâ. Tourism and Recreation, 2(2), 46-58.

Bucak, T. ve Yiğit, S. (2020). The future of the chef occupation and the food and beverage sector after the covid-19 outbreak: Opinions of Turkish chefs. International Journal of Hospitality Management, 92, 1-8. Doi: https://doi.org/10.1016/j.ijhm.2020.102682.

CaliBurger. (2016). Meet Flippy, our new kitchen assistant. 2 Mart 2021 tarihinde https://caliburger.com/: https://caliburger.com/flippy adresinden erişildi.

Cambridge Dictionary. (2021). Meaning of Robot in English. 28 Mayss 2021 tarihinde https://dictionary.cambridge.org/dictionary/english/robot adresinden erişildi.

Chan, A., P., H. ve Tung, W., V., S. (2019). Examining the effects of robotic service on brand experience: the moderating role of hotel segment. Journal of Travel \& Tourism Marketing, 36(4), 458-468. 
Collins, G. (2015). The rise of robotics in hospitality, HITEC 2015 special report. 2 Mart 2021 tarihinde https://www.hftp.org/hitec/i/downloads/H15SRw.pdf/ adresinden erişildi.

Crook, J. (2014, Ağustos 13). Starwood introduces robotic butlers at aloft hotel in cupertino. 5 Şubat 2021 tarihinde https://techcrunch.com/2014/08/13/starwood-introduces-robotic-butlers-at-aloft-hotel-in-palo-alto/ adresinden erişildi.

CBS News (2016). Invasion of the pizza-making robots. 4 Şubat 2021 tarihinde https://www.cbsnews.com/news/invasion-of-the-pizza-making-robots/ adresinden erişildi.

Doğan, S. ve Vatan, A. (2019). What do guests think about service robots? A research for reviews on tripadvisor. The Third International Congress on Future of Tourism: Innovation, Entrepreneurship and Sustainability (s.851852). Mersin, Türkiye.

Doyle, T., B. (2018). Go to downtown crossing for a meal cooked by a robot. 10 Şubat 2021 tarihinde Eater Boston: https://boston.eater.com/2018/4/27/17290330/downtown-crossing-robotic-kitchen adresinden erişildi.

Erzincanl1, F. and Sharp, J.M. (1997). A classification system for robotic food handling. Food Control, 8(4), 191-197.

Flandorfer, P. (2012). Population ageing and socially assistive robots for elderly persons: The importance of sociodemographic factors for user acceptance. International Journal of Population Research, 2012, 1-13. doi:https://doi.org/10.1155/2012/829835.

Fondevila Gascón, J. F., Marqués-Pascual, J., Muñoz González, M. and Polo López, M. (2019). The impact of robotics on the tourism sector: the case of Barcelona. Harvard Deusto Business Research, VIII(1), 49-61. doi:https://doi.org/10.3926/hdbr.225.

Fust'e-Forn'e, F. (2021). Robot chefs in gastronomy tourism: What's on the menu?. Tourism Management Perspectives, 37, 1-9. Doi: https://doi.org/10.1016/j.tmp.2020.100774.

Fuentes-Moraleda, L., Díaz-Pérez, P., Orea-Giner, A., Muñoz- Mazón, A. and Villacé-Molinero, T. (2020). Interaction between hotel service robots and humans: A hotel-specific service robot acceptance model (sram). Tourism Management Perspectives, 36, doi:https://doi.org/10.1016/j.tmp.2020.100751. 
Gunasekaran, S. (1996). Computer vision technology for food quality assurance. Trends in Food Science \& Technology, 7, 245-256.

Hamacher, A. (2015, Ağustos 5). Silicon Valley's Crowne Plaza Hotel launches Savioke robot delivery service. 3 Şubat 2021 tarihinde robohub.org: https://robohub.org/silicon-valleys-crowne-plaza-hotel-launchessavioke-robot-delivery-service/ adresinden erişildi.

Han, H., S., Roy, P., K., Hossain, M., I., Byun, K., H., Choi, C. and Ha, S., D. (2021). COVID-19 pandemic crisis and food safety: implications and inactivation strategies. Trends in Food Science \& Technology, 109(11), 2536.

Heater, B. (2018). Flippy, the robot hamburger chef, goes to work. 3 Şubat 2021 tarihinde techcrunch.com: https://techcrunch.com/2018/03/05/flippythe-robot-hamburger-chef-goes-to-work/ adresinden erişildi.

Hertzfeld, E. (2019). Japan's Henn Na Hotel fires half its robot workforce. 3 Şubat 2021 tarihinde Hotel Management: https://www.hotelmanagement.net/tech/japan-s-henn-na-hotel-fires-half-its-robot-workforce adresinden erişildi.

Hertzfeld, E. (2018). Alibaba Group unveils its first 'future hotel'. 28 Mayıs 2021 tarihinde Hotel Management: https://www.hotelmanagement.net/tech/alibaba-group-unveils-its-first-future-hotel adresinden erişildi.

Holley, P. (2018). The Boston Restaurant where robots have replaced the chefs. 1 Şubat 2021 tarihinde The Washington Post: https://www.washingtonpost.com/news/innovations/wp/2018/05/17/will-robots-replacechefs-at-this-new-boston-restaurant-they-already-have/ adresinden erişildi.

Holmes, J. (2014). Developing a washable robot for poultry processing. 1 Mart 2021 tarihinde http://gtri.gatech.edu/casestudy/developing-washab-le-robot-poultry-processing adresinden erişildi.

International Federation of Robotics. (2020). Service robots. 3 Mart 2021 tarihinde international federation of robotics: https://ifr.org/servicerobots adresinden erişildi.

International Organization for Standardization (2012). ISO/CD 8373. Robots and robotic devices-vocabularyhttps://www.iso.org/standard/75539.html. adresinden erişilmiştir.

Ivanov, S. (2020). The impact of automation on tourism and hospitality jobs. Information Technology \& Tourism, 22, 205-215. 
Ivanov, S. ve Webster, C. (2017). Adoption of robots, artificial intelligence and service automation by travel, tourism and hospitality companies- a cost-benefit analysis. International scientific conference contemporary tourismtraditions and innovations. 19-21 October 2017, Sofia University.

Ivanov, S., Webster, C. and Berezina, K. (2017). Adoption of robots and service automation by tourism and hospitality companies. Revista Turismo $\mathcal{E}$ Desenvolvimento, 27(28), 1501-1517.

Ivanov, S. and Webster, C. (2019a). Perceived appropriateness and intention to use service robots in tourism. J. Pesonen ve J. Neidhardt (Eds.). Information and communication technologies in tourism 2019 içinde (s.237248). Proceedings of the international conference in Nicosia, Cyprus, 30.01-01.02.2019. Cham: Springer.

Ivanov, S. and Webster, C. (2019b). What should robots do? a comparative analysis of industry professionals, educators and tourists. J. Pesonen ve J. Neidhardt (Eds.). Information and communication technologies in tourism 2019 içinde (s.249-262). Proceedings of the international conference in Nicosia, Cyprus, 30.01- 01.02.2019. Cham: Springer.

Ivanov, S. and Webster, C. (2020). Robots in tourism: A research agenda for tourism economics. Tourism Economics, 26(7), 1065-1085.

Ivkov, M., Bleši'c, I., Dudi'c, B., Pajtinková Bartáková, G. and Dudi'c, Z. (2020). Are future professionals willing to implement service robots? Attitudes of hospitality and tourism students towards service robotization. Electronics, 9(1942), 1-16.

İbiş, S. (2019). Turizm endüstrisinde robotlaşma. Türk Turizm Araştırmaları Dergisi, 3(3), 403-420.

Jarvis, H. (2016). Robot-Run Hotel gets Guinness approval.2 Mart 2021 tarihinde https://standbynordic.com/ robot-run-hotel-gets-guinness-approval/ adresinden erişildi.

Khan, Z. H., Khalid, A. and Iqbal, J. (2018). Towards realizing robotic potential in future intelligent food manufacturing systems. Innovative Food Science E Emerging Technologies, 48, 11-24.

Kılıçhan, R. ve Yılmaz, M. (2020). Artificial intelligence and robotic technologies in tourism and hospitality industry. Erciyes Üniversitesi Sosyal Bilimler Enstitüsü Dergisi L, 3, 353-380.

Kinder Travel Guide. (2021). Hajime Robot Restaurant. 6 Mart 2021 tarihinde https://kindertravelguide.com/travel-directory/hajime-robot-restaurant/ adresinden erişildi. 
Kopp, J. (2019, Ağustos 28). Meet 'Sally,' jefferson health's new salad-dishing robot. 1 Mart 2021 tarihinde https://www.phillyvoice.com/thomas-jefferson-hospital-robot-salad-healthy-food/ adresinden erişildi.

Kuo, C.-M., Chen, L.-C. and Tseng, C.-Y. (2017). Investigating an innovative service with hospitality robots. International Journal of Contemporary Hospitality Management, 29(5), 1305-1321.

Lin, P., Abney, K. ve Bekey, G. (2011). Robot ethics: Mapping the issues for a mechanized world. Artificial Intelligence, 175(5-6), 942-949.

Lu, L., Cai, R. and Gursoy, D. (2019). Developing and validating a service robot integration willingness scale. International Journal of Hospitality Management, 80, 36-51.

Lu, L., Zhang, P. and Zhang, T.(C). (2021). Leveraging "human-likeness" of robotic service at restaurants. International Journal of Hospitality Management, 94, 1-9. https://doi.org/10.1016/j.ijhm.2020.102823.

Mahalik, N.,P. and Nambiar, Y. (2009). Extending field bus standards to food processing and packaging industry: A review. Computer Standards $\mathcal{E}$ Interfaces, 31(3). 586-598.

Mathath, A. and Fernando, Y. (2017). Robotic transformation and its business applications in food industry, s.281-305. 29 Mayis 2021 tarihinde https://www.researchgate.net/publication/313474243_Robotic_Transformation_and_its_Business_Applications_in_Food_Industry adresinden erişildi.

Mil, B. and Dirican, C. (2018). Endüstri 4.0 teknolojileri ve turizme etkileri. Jomat Disiplinlerarası Akademik Turizm Dergisi, 1(3), 1-9.

Moon, M. (2018, May1s 4). Robotic woks are the chefs in this Boston Restaurant. 5 Şubat 2021 tarihinde https://www.engadget.com/2018-05-04-bostonrobotic-kitchen-spyce.html adresinden erişildi.

Murphy, J., Hofacker, C. and Gretzel, U. (2017). Dawning of the age of robots in hospitality and tourism: Challenges for teaching and research. European Journal of Tourism Research, 15, 104-111.

Murphy, J., Gretzel, U. and Pesonen, J. (2019). Marketing robot services in hospitality and tourism: the role of anthropomorphism. Journal of Travel $\mathcal{E}$ Tourism Marketing, 36(7), 784-795.

Nguyen, C. (2016, Temmuz 26). Restaurants in China are replacing waiters with robots. 04 Mart 2021 tarihinde https://www.businessinsider.com/-chinese-restaurant-robot-waiters-2016-7 adresinden erişildi. 
Papathanassis, A. (2017). R-tourism: Introducing the potential impact of robotics and service automation in tourism. Ovidius University Annals, Economic Sciences Series, Ovidius University of Constantza, Faculty of Economic Sciences, 1, 211-216.

Pieska, S., Luimula, M., Jauhiainen, J. and Spiz, V. (2013). Social service robots in wellness and restaurant applications. Journal of Communication and Computer, 10, 116-123.

Prentice, C.; Lopes, S., D. and Wang, X. (2020). The impact of artificial intelligence and employee service quality on customer satisfaction and loyalty. Journal of Hospitality Marketing \& Management, 29(7), 739-756.

Reis, J., Melão, N., Salvadorinho, J., Soares, B. and Rosete, A. (2020). Service robots in the hospitality industry: The case of Henn-na hotel, Japan. Technology in Society, 63(C), https://doi.org/10.1016/j.techsoc. 2020.101423

Reisinger, D. (2016). Pizza Hut adding "Pepper robots" to restaurants in Asia. 1 Mart 2021 tarihinde http://in.pcmag.com/robotics-automation/103569/news/pizza-hut-adding- pepper-robots-to-restaurantsin-asia adresinden erişildi.

Restaurant Technology News. (2019). Restaurant technology spotlight: AUTEC sushi robots. 20 Şubat 2021 tarihinde https://restauranttechnologynews.com/2019/10/restaurant-technology-spotlight-autec-sushi-robots/ adresinden erişildi.

Robinson, M. (2018). This startup is raising $\$ 750$ million to outmaneuver Domino's and Pizza Hut with pizzas made by robots. 2 Mart 2021 tarihinde https://www.businessinsider.com/zume-pizza-robot-expansion2017-6 adresinden erişildi.

Royal Caribbean International. (2021). Bionic bar. 5 Mart 2021 tarihinde Royal Caribbean International: https://www.royalcaribbean.com/cruisedining/bionic-bar adresinden erişildi.

Sedacca, M. (2016, Ağustos 29). Are robots really destined to take over restaurant kitchens?. 3 Mart 2021 tarihinde https://www.eater.com/2016/8/29/12660074/robot-restaurant-kitchen-labor adresinden erişildi.

Seyitoğlu, F. ve Ivanov, S. (2020). Service robots as a tool for physical distancing in tourism. Current Issues in Tourism, 1-4. Doi: http://dx.doi.org/doi: 10.1080/13683500.2020.1774518. 
Silverstein, E. (2020). Robot bartender at the bionic bar on Royal Caribbean Cruises.1 Mart 2021 tarihinde https://www.cruisecritic.com/articles.cfm?ID=2454 adresinden erişildi.

The Smart Local Tailand. (2020). This Japanese buffet restaurant in bkk has a robot who waits tables and dances. 03 Mart 2021 tarihinde The Smart Local Tailand: https://hesmartlocal.com/thailand/hajime-robot-restaurant/ adresinden erişildi.

Travelzoo (2016). Travellers expect robots on their holidays by 2020. 7 Mart 2021 tarihinde https://www.prnewswire.com/news-releases/travellers-expect-robots-on-their-holidays-by-2020-571461481.html adresinden erişildi.

Trejos, N. (2016). USA Today, introducing Connie, Hilton's new robot concierge. 8 Mart 2021 tarihinde https://www.usatoday.com/story/travel/-roadwarriorvoices/2016/03/09/introducing-connie-hiltons-new-robot-concierge/81525924/adresinden erişildi.

Trienekens, J. and Zuurbier, P. (2008). Quality and safety standards in the food industry. International Journal of Production Economics, 113(1), 107-122.

Tung, V., W., S. and Law, R. (2017). The potential for tourism and hospitality experience research in human-robot interactions. International Journal of Contemporary Hospitality Management, 29(10), 2498-2513.

Tussyadiah, I. (2020). A review of research into automation in tourism: launching the annals of tourism research curated collection on artificial intelligence and robotics in tourism. Annals of Tourism Research, 81(3). 1-13.

Tussyadiah, I., P., Zach, F., J. and Wang, J. (2020). Do travelers trust intelligent service robots?. Annals of Tourism Research, 81, 1-14.

Türk Dil Kurumu. (2021). Güncel Türkçe sözlük. 28 Mayıs 2021 tarihinde https://sozluk.gov.tr/ adresinden erişildi.

Van Doorn, J., Mende, M., Noble, S., M., Hulland, J., Ostrom, A., L., Grewal, D. and Petersen, J., A. (2017). Domo arigato mr. roboto: emergence of automated social presence in organizational frontlines and customers 'service experiences. Journal of Service Researh, 20(1), 43-58.

Vatan, A. ve Doğan, S. (2021). What do hotel employess think about service robots? A qualitative study in Turkey. Tourism Management Perspectives, 37, 1-10. 
Wilson, M. (2010). Developments in robot applications for food manufacturing. Industrial Robot: An International Journal, 37(6), 498-502.

Wirtz, J., Patterson, P. G., Kunz, W. H., Gruber, T., Lu, V. N., Paluch, S. and Martins, A. (2018). Brave new world: Service robots in the frontline. Journal of Service Management, 29(5), 907-931. https://doi.org/10.1108/JOSM-04-2018-0119.

www.akinsoft.com.tr (2015). Garson robot Ada Cadde Meram Kafe \& Robotik Uygulama Merkezi'nde hizmete başladı. 4 Şubat 2021 tarihinde https://www.akinsoft.com.tr/as/etkinlik/kutlamalar/sosyal/2015/cadde_meram/adresinden erişildi.

www.akinsoft.com.tr (2019). İnsansı robot Mini ADA İstanbul Havalimanı'nda göreve başlıyor. 22 Şubat 2021 tarihinde https://www.akinsoft.com.tr/medya-merkezi/request.php?q=akinsoft-Miniada-istanbul-havalimani-6940 adresinden erişildi.

www.designboom.com. (2010). China's first robot restaurant. 3 Mart 2021 tarihinde designboom: https://www.designboom.com/technology/chinas-first-robot-restaurant/ adresinden erişildi.

www.bcg.com (2015). The robotics revolution: the next great leap in manufacturing. 14 Nisan 2021 tarihinde https://www.bcg.com/publi-cations/2015/lean-manufacturing-innovation-robotics-revolution-nextgreat-leap-manufacturing / adresinden erişildi.

www.hostitalitynet.org (2018). Millennium Hotels and Resorts deploys robotic solutions to its Singapore properties. 10 Mart 2021 tarihinde https://www.hospitalitynet.org/news/4090560.html adresinden erişildi.

www.turkiyeturizm.com (2010). Çin'de lokantada garson robotlar. 1 Mart 2021 tarihinde https://www.turkiyeturizm.com/cinde-lokantada-garson-robotlar-32365h.htm adresinden erişildi.

Yalçın Kayıkçı, M. ve Kutluk Bozkurt, A. (2018). Dijital çağda z ve alpha kuşağı, yapay zekâ uygulamaları ve turizme yansımaları. Sosyal Bilimler Metinleri, 1, 54-64.

Yıldız, S. (2018). Profesyonel turist rehberlerinin teknolojik rehber algısını belirlemeye yönelik bir araştırma: İstanbul örneği. Journal of Social and Humanities Sciences Research, 5(31), 4686-4697.

Yıldız, S. (2019). Turist rehberliği mesleğinde robot rehberlerin yükselişi. Süleyman Demirel Üniversitesi Vizyoner Dergisi, 10(23), 164-177. 
Yülek, M, (2018). 11. Kalkınma Planı ve Türkiye'nin robotları. 2 Mart 2021 tarihinde https://www.dunya.com/kose-yazisi/11-kalkinma-plani-veturkiyenin-robotlari/401624 adresinden erişildi.

Zhu, D., H. and Chang, Y., P. (2020). Robot with humanoid hands cooks food better?. International Journal of Contemporary Hospitality Management, 32(3), 1367-1383.

\section{Kaynakça Bilgisi / Citation Information}

Özgürel, G. ve Kılınç-Şahin, S. (2021). Turizmde robotlaşma: Yiyecekiçecek sektöründe robot şefler ve robot garsonlar. OPUS-Uluslararası Toplum Araştırmaları Dergisi, 18(Yönetim ve Organizasyon Özel Sayıs1), 1849-1882. DOI: 10.26466/opus.899296. 